\title{
The Mystical Force of Money
}

\section{Edward Erikson}

\author{
All things exchange for fire, and fire for all things - \\ Heraclitus
}

W hen Marx broaches the question of money in the Economic and Pbilosophic Manuscripts of 1844 he does not turn to the political economists for an explanation, as one might expect, but rather to the poets and playwrights. In a reading of William Shakespeare's Timon of Athens Marx tells us that "Shakespeare excellently depicts the real nature of money." The play follows the decent of Lord Timon from riches to wretchedness as usurers redeem their debts and exhaust the Lord's estate. As the play unfurls, Timon undergoes a traumatic transformation from a kind hearted and compassionate aristocrat to seething misanthrope. Timon is exiled from Athens and takes shelter in the forest outside the city. Then, in a twist of fate, he stumbles upon a new found fortune. Lord Timon ironically proclaims "Gold? Yellow, glittering, precious gold? No, Gods, I am no idle votarist!... Thus much of this will make black white, foul fair, wrong, right, base noble, old young, coward valiant..."2 Marx quotes from this scene in the Manuscripts and suggests that money, the real nature of money, appears replete with its many magical powers. Money makes possible a universal exchange of both tangible objects that meet each other in the marketplace as well as the intangible human qualities such as courage, beauty, intelligence, etc. Timon himself displays all these qualities when he is wealthy and their opposites when he is poor. We discover in the money-form King Midas incarnate: it transforms all that it touches so that one who possesses money takes on the qualities of money itself. The universal exchange crushes difference and reduces all to a single denomination. In the Manuscripts Marx's writes "what I am and am capable of is by no means determined by my individuality." 3 The money-form sets the limits and bounds of one's own horizon. "If I have no money for travel" Marx's writes, "I have no need for travel...If I have the vocation for study but no money for it, I have no vocation for study." 4 The singularity of money, he argues, becomes the sole delimiting factor for social, cultural and economic relationships.

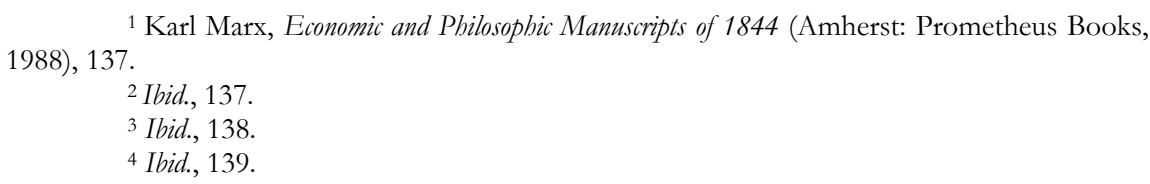

(c) 2010 Edward Erikson http://www.kritike.org/journal/issue 8/erikson december2010.pdf ISSN 1908-7330 
According to some readings, Marx moves away from these literary descriptions and humanist concerns in Capital Vol. I and turns instead to a scientific engagement and explanation of the value-form of money. Ernest Mandel writes, "Marx was convinced that the cause of the proletariat was of decisive importance for the whole future of mankind, he wanted to create for that cause not a flimsy platform of rhetorical invective or wishful thinking, but the rock-like foundation of scientific truth." 5 Thus, we find the "real nature of money" re-presented in Capital in an algebraic cloak. Marx writes "The whole mystery of the form of value lies hidden in this simple form...x commodity A = $\mathrm{y}$ commodity B." 6 Marx seeks to explain away the 'dazzling' quality of the money-form through an analysis of this simple equation. But even when the mystery has been lifted, the mystical force of money remains. I suggest that traces of the 'dazzling' form and the humanist concerns linger in the figurative and performative function of language in Capital. I seek to draw out these traces by reading the origins of the money-form in Capital Vol. I through the Economic and Pbilosophical Manuscripts of 1844. A reading, I suggest, that disrupts the scientific discourse that Mandel argues frames Capital, blurring the line between literary and scientific.

Theorists have indicated a sharp distinction between Marx early and late work. Some draw the line between alienation theory and economic determinism, others, such as Louis Althusser, as an epistemological break in The German Ideology. Kojin Karatani, however, argues that such a division overlooks "the incessant transpositions and turns" in Marx's thought. Karatani writes "Marx's thinking should be read in reference to the "microdifferences" within similarities and proximities." Following Karatani, I examine the micro-differences and similarities between these two texts in order to un-cover the transformative force and violence implicit in the concept of money as the universal exchange form. I tease out the figurative language and literary tropes, focusing specifically on the tension between the scientific and descriptive language of Marx's work. I argue that the performative function of language animates commodities so that they appear before us as humans; and, conversely, cast upon humanity the thingly likeness of the commodity.

\section{Beyond the Bounds of Science}

The (Un)Natural form of $V$ alue

We encounter the commodity in the market place donning money like a carnival costume mask. Commodities, however, are not born in the market place; rather, Marx tells us, "Commodities come into the world in the form of use-values or material goods, such as iron, linen, corn, etc. This is their plain, homely, natural form." He immediately qualifies this statement, writing, "they

${ }^{5}$ Ernest Mandel, “Introduction,” in Capital, Vol. I (London: Penguin Books, 1990), 17.

${ }^{6}$ Karl Marx, Capital, Volume I (London: Penguin Books, 1990), 139.

${ }^{7}$ Kojin Karatani, Transcritique (Cambridge: The MIT Press, 2005), 161.

8 Ibid., 164.

${ }^{9}$ Marx, Capital, Volume I, 138. 
are only commodities because they have a dual nature..."10 Marx indicates that commodities are first and foremost a concrete object with a particular or specific use. Yet, his conception of the natural form of the commodity points to a contradiction: commodities come into the world not as their natural form but as both a natural form and a value form. They bear both a material body and an immaterial value. According to his analysis, commodities would not be commodities without this dual nature. Thus, they are always-already unnatural. If we abandon the distinction between natural and unnatural, it becomes increasingly evident that both the function and value of a commodity are determined by social convention not the intrinsic qualities of the items themselves. In other words, use-value as well as exchange-value depends upon society. What is the meaning then of this distinction? Why does Marx cast commodities in the light of natural form?

The social constitution of the commodity contains an immediate problem for the notion of scientific analysis. Marx writes "The objectivity of commodities as values differs from Dame Quickly in the sense that 'a man knows not where to have it'. Not an atom of matter enters into the objectivity of commodities as values; in this it is the direct opposite of the coarsely sensuous objectivity of commodities as physical objects."11 While the physical form (natural) immediately presents itself to us as an object, the immaterial or exchange value eludes us. Marx playfully turns to Shakespeare's Henry IV to point to the mysterious mystical form of value, the very thing that evades the scientific eye. He goes on to write, "We may twist and turn a single commodity as we wish; it remains impossible to grasp it as a thing possessing value."12 The literary allusion momentarily releases Marx from the discourse of scientific objectivity. The quote suggests that something else may be operating within the exchange value of a commodity that exists outside the bounds of science. Marx, however, does not linger long in this space. While it is not immediately visible, he writes "commodities possess an objective character as value only in so far as they are all expressions of...human labour."13 Thus he locates an objective measure of value operating within the realm of the social. The problem persists for the physical form of the commodity. The quote begins by taking the physical, natural form for granted. We can grasp it therefore it exists. The contradiction implicit in the origin of the commodity, however, suggests that the natural form requires closer examination.

The natural form provides a foil against which the mystery of the immaterial form appears to us. While Marx relies upon the distinction between the natural and social to explain why the objective quality of one form (the material) is present while the other form (immaterial) is hidden, the distinction remains problematic. The material form of the commodity, as I have suggested, is not determined by its objective physical characteristics, but by its

\footnotetext{
${ }^{10}$ Ibid., 138.

${ }^{11}$ Ibid.

${ }^{12}$ Ibid.

${ }^{13}$ Ibid.
} 
use. Thus, it too operates purely in the social realm. Why then is one form visible and the other concealed?

Alongside the natural and unnatural form, a figurative distinction implicitly persists between the homely form (natural) and dazzling form (social) which may be more telling. The figurative distinction indicates the opposite from that of scientific analysis. While the objective characteristics of the natural form can be measured, weighed, objectified and analyzed, the adjective homely suggests that the physical form goes unnoticed or overlooked. Conversely, the value form may be invisible to the scientist, but all eyes are drawn to the dazzling quality of the commodity. Thus the figurative language produces a tension within in the text. While adjectives may be deployed to sweeten the descriptions, we find that they can also produce alternative and competing meanings. Natural and homely, for example, are not synonymous. While natural objects are of the earth, they too may be magnificent, dazzling or awefull. Homely, qualifies the term natural rather than complementing it. It suggests that the natural form is plain, commonplace, etc. and consequently, unworthy of attention. It dismisses the "natural form" of the commodity. Thus, it is not just overlooked, but unworthy of looking. The dazzling form suggests the opposite. The word dazzling signifies a strange hypnotic power. The value is not invisible, but rather hyper-visible. The figurative language points to a non-objective quality present within both the physical and value form of the commodity. It allows Marx to take up a dual position in the text: at once to be a scientist, yet to observe that which the scientist cannot see.

The money form bears a certain analogy to adjectives: they are both an epidermal form. Just as we encounter Marx analysis wrapped up in adjectives, value too is covered-over by the money-form. Marx's expressed aim is to strip away the skin and reveal a deeper truth: the blood of our flesh and marrow of our bones. He promises to break the captivating spell by stripping the commodity of the money-form and revealing value for what it is: congealed labour-power. Nevertheless, the mysterious force of money persists: not beneath the skin or behind the veil as he seeks to show us, but in the veil itself, the very thing he wishes to discard.

\section{Bebind the Dazilling Veil}

The mystery of the value-form is bound up in corporeal manifestation of value. Money simultaneously covers and un-covers value. At once we can grasp the money-form, touch it, worship it, yet the whole time, the objective value of the commodity remains out of reach. What is more, the dazzling form of money further obscures the objective value. In order to dissolve this mystery Marx turns to the origins of the money-form, a task, he claims "never even attempted by bourgeois economics..."14 Marx writes, "we have to trace the development of the expression of value contained in the value-relation of commodities from its simplest, almost imperceptible outline to the dazzling money-form. When this has been done, the mystery of money will 
immediately disappear."15 The story of the origin that unfolds is both historical and algebraic.

The money-form and the commodity are intimately related, yet have two different origins. The commodity ostensibly originates from the earth (natural form), while the money-form grows out of the commodity itself. Marx writes, "The simple commodity form is...the germ of the money-form."16 The origin of money, then, is revealed in the "simple" equation:

$$
\mathrm{x} \text { commodity } \mathrm{A}=\mathrm{y} \text { commodity } \mathrm{B} \text { or: } \mathrm{x} \text { commodity } \mathrm{A} \text { is }
$$
worth y commodity B

The equation, however, poses a unique problem of translation and analysis. Specifically, how are we to read the equal sign? The equation immediately appears to us in two forms: one as expressed equality via the mathematical symbol and the second as the translation into English as worth. Yet, an expression of worth differs significantly from that of equality: the former is an expression of value while the latter is an expression of properties. Furthermore, in Marx's description and analysis that follows, the symbol takes on at least one other meaning: equivalence. Are we then to read these three concepts as interchangeable?

The issue of worth and equivalence are connected to the expression of value. The equation suggests that value is co-constituted within the relationship between commodities. Marx writes "the linen expresses its value in the coat; the coat serves as the material in which that value is expressed."17 Thus each commodity simultaneously embodies both value and an expression of value. Commodities are made equivalent, in so much as one is capable of expressing the value of another. Furthermore, the expressed value signifies the worth. The two commodities, however, are not equal. Marx writes "I cannot, for example express the value of linen in linen. 20 yards of linen $=20$ yards of linen is not an expression of value." 18 The value statement is only meaningful in so much as the two materials differ. In other words, value can only be expressed through difference. While the two commodities meet each other as "equals", as capable of mutual exchange, they are not equal in objective measure (size, shape, weight, substance). Not only is there an expressed inequality, the value relationship depends upon this inequality.

The equal sign, perhaps, points to a deeper reality. Marx writes, "In the expression of value of the linen, the usefulness of tailoring consists, not in making clothes, and thus also people, but in making a physical object which we at once recognize as value, as a congealed quantity of labour."19 Regardless of the material difference between the two commodities their value originates from the same place: labour. More specifically the equal sign points to the

\footnotetext{
15 Ibid., 139.

16 Ibid., 163.

17 Ibid., 139.

18 Ibid., 140.

${ }^{19}$ Ibid., 150.
} 
direct relationship between value and the expenditure of labour power. The polysemus equal sign allows Marx to play upon the concept of equality in a way that problematizes the concept of value. At the same time, this veil of equality reveals the mystery of money: the universal exchange value.

The value-form develops out of the relationality between commodities but then becomes crystallized in the money-form. While Marx has uncovered the common denominator of commodities (labor), a mystical force remains in the function of money as the universal exchange form. Marx further seeks to explain away the mystery by turning to the historical context in which the money-form arises. He maps the shift of the expression of value from commodity to money. Marx notes that while nomadic peoples were the first to develop money, the concept of money reached fruition at the end of the seventeenth century during the French revolution. He writes, "Men have often made man himself into the primitive material of money, in the shape of the slave, but they have never done this with the land and the soil." And then adds, "Such an idea could only arise in bourgeois society." ${ }^{20}$ Capitalism marks the moment when the money-form comes to encompass the totality of society. The analogy between human slavery and capitalism hints at the nature of capitalism itself. Money contains the power and force to extend the system of slavery over all life. Money itself has become the master. The analogy echoes the Economic and Philosophical Manuscripts of 1844 where Marx writes 'Money is the pimp between man's need and the object, between his life and his means of life." 21 In both Capital and the Manuscripts money is a medium through which everything passes. Money asserts a powerful force that commands all things, commodities and humans alike.

In examining the process of transformation from a commodity to money-form, Marx writes, "what appears to happen is not that a particular commodity becomes money because all other commodities express their values in it, but, on the contrary, that all other commodities universally express their values in a particular commodity because it is money."22 Money is the universal form of exchange value. While it takes the form of value, it is not the object of value itself. Nevertheless, these two concepts (value and value-form) have often been mistakenly conflated within the money form. Marx himself comes close to committing the very error of which he warns the reader. He notes that certain commodities, such as gold and silver, are "by nature" best suited for the money-form. Again, the discourse of natural and nature becomes highly problematic. Precious metals are no more or less suited for money that numerous other materials (linen, iron, stone, paper, etc.) The emphasis of the natural form places undo significance on the form itself ignoring the social context which has granted this material primacy. Thus Marx seeks to lift the veil of mystery surrounding the money-form, but he adds to this mystery by suggesting the gold and silver are imbued by nature to occupy the value-form.

${ }^{20}$ Ibid., 183.

${ }^{21}$ Marx, Economic and Philosophic Manuscripts of 1844, 136.

22 Marx, Capital, Volume I, 187. 
Marx's argument comes to turn upon this false conflation. He writes, "the physical object, gold or silver in its crude state, becomes, immediately on its emergence from the bowels of the earth, the direct incarnation of all human labour. Hence the magic of money." 23 The concept of money appears before us in a capitalist system as if it had existed from time immemorial. By locating value outside of the money-form within the exertion of labour power Marx dispels this conception of the money-form. Marx, however, does not disprove the magical quality through empirical science; rather he renders it absurd and dispels it via irony ("Hence the magic of money). Marx plays with the scientific discourse by interjecting literary tropes. In one sense, this play may point to the outer limits of scientific inquiry, but in another sense it merely suggests an extra-scientific element operating in the text. By stripping gold and silver of their magical properties Marx reveals a fundamental violence at work within the relationship between people and commodities. At the heart of the commodity lies the severed and alienated labour-power that has been extracted from the worker. The trope of irony allows the language to communicate violence with a force that extends beyond the words themselves. While a scientific discourse tends to nullify violence by abstracting capitalism in algebraic equations or by reducing everything to an objective measure, irony exposes a barbed edge.

Marx lifts the dazzling veil, as he promises, yet the mystery and the magic of the money form persist. The question then remains: Does the force of money as universal exchange depend upon this magic or has Marx scientific analysis simply described in algebra what Shakespeare depicted so elegantly? I turn here to the treatment of the commodity itself and suggest that a mystical force remains tied to the universal exchange regardless of Marx's analysis. The presence of the mystical force points to a deeper relationship between people and commodities than Marx's analysis explicitly states.

\section{The Night of the Living Dead}

The Personification of Commodities

"Commodities come into the world..." Marx tells us, yes, they come into the world, but they do not come to us as newborns as one might infer; but rather, returning from the dead. We encounter commodities in Capital, not as passive objects, but lively creatures. Marx's use of figurative language animates the dead labour instilled in each commodity. He endows them with human-like thoughts, language, emotion, agency, etc. The trope of personification pushes commodities into the human dimension and conversely, binds humans with the world of the commodity. Thus, the humanist concern that ostensibly faded from view in Marx's later work remains present in Capital, though hidden, in the figurative language and particularly in the trope of personification.

In Capital, not only do commodities speak, but they speak with a language all their own. Marx suggests that a commodity "reveals its thoughts

${ }^{23}$ Ibid., 187. 
in a language with which it alone is familiar, the language of commodities." 24 This description brings up an array of questions, but bears at least two consequences for the sake of this reading: it presents commodities with human-like qualities and, perhaps connected; it grants the commodity a certain measure of agency.

The metaphor of language points to the internal logic and relationality of capitalism: the function of universal exchange. On the one hand commodities communicate with and through each other an expression of value. On the other hand the money-form communicates the value of the commodities to the marketplace. Thus commodities communicate to each other in a private language (a language all their own) and to people through the one universal language (money). The twofold level of communication binds humans and commodities by a common language so that each appears as the other. At the same time it suggests the possibility of miscommunication (the translation between the private and public language).

The value form of money becomes the universal expression of value for humans as well as commodities. Just as the value of linen can be expressed by a coat, so too can the value of humanity be expressed by a commodity. Thus, not only does it draw into comparison commodities and humans, it renders them equivalent. In the Economic and Philosophical Manuscripts Marx writes, "Since money, as the existing and active concept of value, confounds and exchanges all things, it is the general confounding and compounding of all things - the world upside-down - the confounding and compounding of all natural and human qualities." 25 We see here an equivalency but also a distortion. There is communication, but also miscommunication. Marx writes that the commodity "reads all prices backwards, and thus as it were mirrors itself in the bodies of all other commodities, which provide the material through which it can come into being as a community."26 Money gains life through a perverse dyslexia where the exchange value takes precedence over the use-value.

The power of language grants commodities a certain semblance of agency. The verb to speak, to read, to think etc. are all connected to a concept of language, an engagement with language and tied to a notion of autonomy. There is a tension, however, within the text: commodities have agency yet are rendered passive. What's more, we discover that the commodity is made passive through force. Marx writes "Commodities are things, and therefore lack the power to resist man. If they are unwilling, he can use force; in other words, he can take possession of them." 27 Marx explicitly locates commodities as objects antithetical to humanity. Nevertheless, there remains a semblance of agency in this statement. He writes, "if they are unwilling" the turn of phrase suggests that they have the power to do the very thing he says they cannot do: resist. Such resistance not only points to their extra-thingly power but also to

24 Ibid., 143.

${ }^{25}$ Marx, Economic and Philosophic Manuscripts of 1844, 140.

${ }^{26}$ Marx, Capital, Volume I, 205.

${ }^{27}$ Ibid., 178. 
the force implicit within the money-form. The money-form may not be the Rosetta stone that allows us to translate the language of commodities, but rather an external imposition forced upon them, a translation provided by the colonist. The personification suggests that the fate of commodities may mirror that of humanity. The violence enacted upon the commodity becomes a metaphor for the violence enacted upon the people through the appropriation of their labor-power in a capitalist economy.

Marx, of course, gets caught up in his own metaphor of language and again we find ourselves trying to reconcile contradictions. While Marx tells that commodities speak, just a few pages later he writes "If commodities could speak, they would say this: our use-values may interest men, but it does not belong to us as objects. What does belong to us as objects, however, is our value." 28 The statement implies that commodities cannot speak, that they do not possess language. Nevertheless Marx goes ahead and tells us what they would say if they could speak. Marx is less a translator and more a medium conjuring the essence of a ghost. The contradiction reveals that Marx's observations regarding the nature of the value-form of capital are never-not-yet scientific but metaphoric. Such an observation disrupts the way in which one may traditionally read capital as a text of political economy or as a faithful description of capitalism. By adopting figurative techniques, Marx comes to reveal a deeper nature of the value-form of money: a mystical force that resists objectification.

Beyond the commodities capacity for language resides the realm of emotion. Not only do commodities speak, but they display other human qualities as well. Marx writes, "We see then that commodities are in love but that 'the course of true love never did run smooth."' 29 The metaphor of love describes the phenomena of the social division of labor and the effect it has had on prices. Marx writes, "What was yesterday undoubtedly labour-time socially necessary to the production of a yard of linen ceases to be so today." 30 Each commodity expresses the value of the other, but these values have been manipulated by the capitalist. Thus, Marx extends the capacity of human emotion to the commodity. The metaphor suggests the very dazzling nature of the money-form: all things exchange for money. Love becomes money, money becomes love. Moreover, the analysis marks another Shakespearean intervention. The quote comes to us from Lysander in A Midsummer Night's Dream. Unlike the Economic and Philosophical Manuscripts of 1844, however, the quotes he draws from Shakespeare, et al remain implicit allusions rather than explicit exegesis. Marx no longer tells us that the 'real nature of money' reveals itself to us in these literary texts, yet the sentiment remains inferred. 
The Commoditization of Humanity

The commodity appears as a mirror reflecting back upon us our own image. Marx writes "There is an antithesis, immanent in the commodity... between the conversion of things into persons and persons into things." 31 The mystical force of money appears in the mirror image: it transforms people into commodities by reducing them to a function of laborpower and rendering them exchangeable. This transformation takes place on both a figurative and a literal level: first, figurative language implicates people in the discourse of commodities through imposition; second, labor power circulates in the market as a commodity.

The commodity seduces us. It requires the human hand to fulfill its function as a commodity and thus implicates us in the world commodities. Marx writes, "Commodities cannot themselves go to market and perform exchanges in their own right." 32 The relationality of commodities permits them to communicate, yet people are the necessary medium through which communication is made possible. Commodities place an imposition on their owner: they require humans to place them in relation with one another. Out of this process of exchange, Marx suggests, comes the money-form. He writes, "Money necessarily crystallizes out of the process of exchange, in which different products of labour are in fact equated with each other, and thus converted into commodities." 33 Yet money remains a secondary not a primary function. It does not permit the exchange, but merely facilitates the exchange. Nevertheless, the money-form reveals for the first time the equivalence of humans and commodities by bringing them together under a single, universalform of value.

The transformative nature of money presented within Timon of Athens, returns again in Capital, although, with a minor difference. In Capital, Marx no longer talks about money specifically (one commodity form) but commodities generally. In the Economic and Philosophical Manuscripts of 1844 Marx's writes "Money is the supreme good, therefore so is its possessor. Money, besides, saves me the trouble of being dishonest: I am presumed honest. I am stupid, but money is the real mind of all things and how then should its possessor be stupid?" 34 Here we see the mirroring at work. The image of money reflects back upon its beholder so that the person takes on the quality of the material. In Capital, however, Marx writes "the natural laws of the commodity have manifested themselves in the natural instinct of the owners of commodities." 35 Similarly, the laws of one are manifested in the other. Humans take on the nature of commodities just as commodities take on the nature of money. With the former, the value of people is expressed by money; with the latter people become commodities that circulate alongside other commodities.

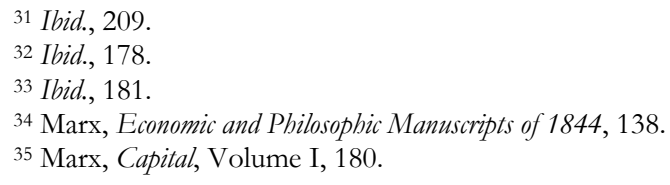


The figurative blurring of humans and commodities complements some of Marx's broader observation of capitalism. He notes, capitalism "arises only when the owner of the means of production and subsistence finds the free worker available, on the market, as the seller of his own labour-power...Capital, therefore announces from the outset a new epoch in the process of social production." "36 Thus, capitalism arises at the moment when humans enter their labour-power into the market as a commodity to be bought and sold. Here, we find the personification of commodities and the commoditization of humans. Perhaps then, we might revise the classic distinction between a young humanist Marx and an old empirical Marx: It's not that Marx's humanist concerns disappear in Capital, but rather, there is no longer a measure of humanity left to concern oneself with.

\section{Re-Reading Capital}

Reading Capital through the Economic and Philosophical Manuscripts of 1844 problematizes the concept of scientific objectivity. While Marx dabbles in the discourse, the play between literary descriptions and scientific observation ultimately causes the distinction between the two to collapse. Scientific observations appear to us packaged in literary allusions, metaphors, adjectives, irony. The figurative nature of the text reveals as much about the nature of capitalism as the more traditional reading of the classical political economists. The language allows Marx to capture a particular emotive quality that helps render the abstract real. The figurative language reveals a fundamental violence at the heart of capitalism which is expressed in the universal exchange form: Money, like fire, exchanges for all things.

The reading suggests first and foremost that the money form is not a passive medium as economists have suggested. Furthermore, that the significance of the money form resides in the form itself, not some concealed truth. A return to the analogy between the adjectival form and the moneyform may help. One can strip all the adjectives from the work (and perhaps some social scientist might try) in order to locate the necessary truth upon which the text of Capital turns. In doing so, the meaning of the text itself would be fundamentally altered. While Marx attempts to strip away the money-form in order to reveal a deeper nature of value, a labor theory of value, the effort detracts from the problem of money itself. By focusing on the surface features and literary elements of the text, an alternative reading opens up in which to approach the money-form: to reclaim rather than reveal the ever-present mystical force of money.

Department of Political Science, University of Massachusetts-Amberst, United States

${ }^{36}$ Ibid., 274. 


\section{MYSTICAL FORCE OF MONEY}

\section{References}

Althusser, Louise, Reading Capital (New York: Verso, 2009).

Colletti, Lucio, "Introduction," in Early Writtings, by Karl Marx (London: Penguin Books, 1992).

Derrida, Jacques, Specters of Marx (New york: Routledge, 1994).

Karatani, Kojin, Transcritique (Cambridge: The MIT Press, 2005).

Mandel, Ernest, "Introduction," in Capital Vol. I, by Karl Marx (London: Penguin Books, 1990).

Marx, Karl, Capital, Volume I (London: Penguin Books, 1990). Economic and Philosophic Manuscripts of 1844 (Amherst: Prometheus Books, 1988). , Grundrisse (New York: Penguin Books, 1973).

Shakespeare, William, The Complete Works of William Shakespeare (New York: Walter J. Black, 1937). 